\title{
Enactment, provision, norm: reflections on the normativeness of provisions regulating the process of legislation
}

\author{
Pawet Grabowski
}

UniWersytet im. A. MickieWicZa, WYdZią PraWA I AdMinistracji, PoZnań

\begin{abstract}
One of the crucial questions considered within the theory of law is the problem of sources of law (fontes iuris oriundi), that is, generally speaking, the ways in which the law is created. Nowadays decisively the most fundamental form of creation of law is the act of legislative understood as a conventional act of a competent public organ performed in accordance with the provisions regulating the process of establishing law. Considering this problem one may give two types of answers found in legal theory papers. Some scholars maintain that those provisions do not have normative character, pointing out that the norms of conduct are not the only basic units of law. According to the second position, provisions regulating the process of legislation do have normative character. This kind of view is represented probably in the most sophisticated form by Zygmunt Ziembinski, who holds that these provisions express a kind of a norm of conduct, namely power conferring norm (norm of a legislative competence), being a type of norm of competence, that is norm granting some competences to perform a definite conventional act. The purpose of my paper is to present both standpoints showing the examples of their most representative supporters. Furthermore, I will try to formulate my own solution to the problem. The concepts of Czesław Znamierowski, Herbert L. A. Hart, Alf Ross and Zygmunt Ziembiński will be presented.
\end{abstract}

1.o Students taking introductory legal courses are constantly referred to the socalled sources of law (in Latin: fontes iuris oriundi): that is, those facts considered to be law-creating ${ }^{1}$. The following types of such facts are distinguished in handbooks: establishment, legal precedents, contracts and custom. According to the principle proposed by Ziembiński, law-creating facts may be associated with the set of rules, that is the rules of validity, which together with the rules of exegesis, that is the rules of interpretation and the rules of inference, compose the normative concept of the sources of law of the given legal order ${ }^{2}$. On the other

${ }^{1}$ See: S. Wronkowska, Podstawowe pojęcia prawa i prawoznawstwa, Poznań 2005, pp. 21-25.

2 More: Z. Ziembiński, Problemy podstawowe prawoznawstwa, Warszawa 1980, pp. 244-311. 


\section{Investigationes Linguisticae, vol. XVII}

hand, one may consider law-creating facts from a theoretical perspective, trying to formulate not a normative theory of the sources of law (that is, theory understood as the system of norms), but a descriptive theory of law (understood as the system of propositions).

Undoubtedly the most fundamental form of sources of law nowadays is establishment, understood as a human act (or a series of conventional acts) of a competent public agent performed in accordance with the provisions regulating the process of establishing law. The result of establishment is a normative act composed of legal provisions from which one reconstructs some legal norms in the process, called the process of interpretation. The legal provisions themselves are not usually sufficient to determine directly what is ordered or prohibited, or to whom, or in what circumstances:. this becomes possible only after the reconstruction of the legal norms embodied in the legal text, which means that those norms are conveyed indirectly.

The aforementioned statement is based on the distinction between provisions and norms ${ }^{3}$. The provision is understood as a basic unit of the legal text, generally in the form of a grammatical sentence provided with an individual name ${ }^{4}$. The legal norm is

understood as the general and abstract norm of conduct, laid down or recognized by a competent state agent, which orders or prohibits specific actions under specific circumstances 5 . What stems from the above definitions is the conclusion that legal provisions are not identical with legal norms, although the latter are reconstructed from the former in the process of interpretation of a legal text. Mostly it is the case that a given norm is reconstructed from many provisions: this feature of a legal text is called fragmentation of norms in legal provisions ${ }^{6}$. It may also happen (and indeed it often does) that a single provision serves for the reconstruction of more than one norm, which in turn is termed by scholars condensation of norms in legal provisions7.

The consequence of reconstruction of legal norms from provisions is that a legal text is considered to have a normative character. Yet one may raise the question of whether every provision in fact has a normative character: in other words, whether every legal provision serves in the process of interpretation to reconstruct at least one element of a certain legal norm. In particular one may ask about the normative character of the provisions regulating the process of the establishment of law. It is this problem, which is one of the most widely discussed issues in contemporary legal theory ${ }^{8}$, which will be the subject of this paper.

2.0 There is a difference of opinion among scholars with respect to the problem of the normative character of the provisions in question. One group (let us call them

\footnotetext{
3 The distinction was proposed by Z. Ziembiński. First time: Z. Ziembiński, Przepis prawny a norma prawna, Ruch Prawniczy, Ekonomiczny i Socjologiczny, nr 1/1960, pp. 105-122.

4 See: S. Wronkowska, M. Zieliński, Problemy i zasady redagowania tekstów prawnych, Warszawa 1993, p. 20.

5 S. Wronkowska, Z. Ziembiński, Zarys teorii prawa, Poznań 2001, pp. 25-26.

${ }^{6}$ For further reading see.: M. Zieliński, Wykładnia prawa. Zasady. Reguły. Wskazówki, Warszawa 2002, pp. 103-126.

7 Ibid, pp. 127-131.

8 As maintained by : M. Atnienza, J. Ruiz, Las piezas del Derecho. Teoría de los enunciados jurídicos, Barcelona 2004, p. 69.
} 
the normative group) maintains that the provisions regulating the process of the establishment of law do have a normative character; while the other (the nonnormative group) opposes that standpoint, holding that the provisions express some other rules. Thus according to the standpoint of the second group, one cannot reduce the law merely to legal norms, since law consists of norms plus other rules of a non-normative character.

It should be stressed that the problem raised in this paper is usually considered in a broader context, and that the solutions proposed by particular scholars are consequently not only applicable to the provisions regulating the process of the establishment of law. The critiques of many scholars, forming the starting point in the development of their own ideas, are frequently based on objections which are irrelevant to the issues considered here. This is especially true in the case of Hart, whose theories will be presented below; subsequently the representatives of the normative group will be discussed, with special attention devoted to the concepts of Zygmunt Ziembiński.

2.1 The starting point in Hart's considerations is a critique of the views of John Austin. Generally speaking, in Austin's theory law is characterized as a general and abstract set of commands from the sovereign backed by threats of punishment in the event of disobedience9. If one gives Austin the benefit of the doubt and assumes he was familiar with the concept of "norm" as described in this paper, then according to contemporary terminology, the law would be defined by Austin as a set of sanctioned and sanctioning norms ${ }^{10}$.

Hart, who is undoubtedly one of the most prominent critics of Austin and the most famous representative of the non-normative group, deals with Austin's theory in his ground-breaking book "The Concept of Law"11. He challenges inter alia Austin's view that the law can be reduced to a set of orders and prohibitions ${ }^{12}$, showing that in particular one cannot reduce the provisions regulating the establishment of law to a pattern of orders of a sovereign backed by the threats of punishment: such a reduction, he maintains, distorts the manner in which these provisions are comprehended in social life ${ }^{13}$.

The concept of law proposed by Hart is based on the differentiation between two types of rule. The first type, called the primary rules, set obligations and seem to fulfill the conditions of the definition of the legal norm given in section 1 above.. The second type, called the secondary rules, do not impose any obligations; rather, they grant some new opportunities of acting. According to Hart, there are three groups of secondary rules, namely: rules of change - which enable the change of the primary rules; rules of adjudication - which determine the authoritative

\footnotetext{
9 J. Austin, The Province of Jurisprudence Determined, Cambridge 1995. Por. J. Stelmach, R. Sarkowicz, Filozofia prawa XIX i XX wieku, Kraków 1998, p. 25.

${ }^{10}$ Regarding the division of norms into "sanctioned" and "sanctioning" see: Z. Ziembiński, Problemy..., op. cit., Warszawa 1980, s. 154-157; M. Zieliński, op. cit., Warszawa 2002, pp. 32-34.

${ }^{11}$ H. L. A. Hart, The Concept of Law, Oxford 1994

12 H.L.A., op. cit., pp. 18-99.

${ }^{13}$ H. L. A. Hart, op. cit., s. 35-42, s. 80. As he states: "The reduction of rules conferring and defining legislative and judicial powers to statements of the conditions under which duties arise has, in the public sphere, a similar obscuring vice" - p. 41.
} 
settlement of the breach of the primary rules; and rules of recognition - which provide instruments to make the authoritative settlement if a given rule is valid or not in a given legal system.

Bearing in mind the subject of the paper, the rules of change seem to be the most interesting of the three since they, as Hart holds, are expressed in the provisions regulating the process of establishing law ${ }^{14}$. As Hart points out, "the simplest form of such a rule is that which empowers an individual or body of persons to introduce new primary rules for the conduct of the life of the group, or of some class within it, and to eliminate old rules. As we have already argued (...) it is in terms of such a rule, and not in terms of orders backed by threats, that the ideas of legislative enactment and repeal are to be understood"15. The author proceeds to characterize the rules in question more precisely: "Such rules of change may be very simple or very complex: the powers conferred may be unrestricted or limited in various ways: and the rules may, besides specifying the persons who are to legislate, define in more or less rigid terms the procedure to be followed in legislation" 16.

In their recently published book "Las piezas del Derecho. Teoria de los enunciados juridicos" Spanish scholars Manuel Atienza and Juan Ruiz summarize Hart's views on the rules of change (which the authors call 'las reglas que confieren poderes') and indicate three features differentiating them from the primary rules. These consist of: their structure, the way in which they influence the practical reasoning of the people, and their influence on public life. As Atienza and Ruiz point out, Hart does not develop his concept in sufficient detailto permit more insightful analysis ${ }^{17}$.

2.2 In contrast to Hart, representatives of the normative group have tried to show that it is possible to reduce the provisions regulating the process of establishing law to legal norms understood in the manner defined above. The normative character of the provisions in question has been maintained inter alias by Hans Kelsen, who in "General Theory of Norms" 18 applies the term "empowering norms"19: "A legal norm empowers certain individuals to create legal norms or to apply legal norms. In such cases we say that the law confers a legal power on certain individuals" 20.

As Kelsen maintains, although the granting of competence is something different from permission ${ }^{21}$ or command, it is linked with an order: "The normative function of empowering is different from the two normative functions of permitting and commanding. But empowering can imply a command. This is so if the power is that of positing norms. (...) If a norm of the constitution empowers the legislative organ to posit general legal norms binding on those

\footnotetext{
14 Anyway it has to be stressed that the rules of change do not only refer to the establishment of law but are also linked with the actions of private persons. See: H. L. A. Hart, op. cit., p. 96.

15 H. L. A. Hart, op. cit., p. 95.

${ }^{16}$ H. L. A. Hart, op. cit., p. 96.

${ }_{17}$ See: M. Atienza, J. Ruiz, op. cit., p. 69.

18 H. Kelsen, General Theory of Norms, Oxford 1991.

19 Anyway Kelsen does not diferentiate expressis verbis the provisions from norms.

${ }^{20}$ H. Kelsen, op. cit., p. 102.

${ }^{21}$ In Kelsen's view there are also so-called permission norms.
} 
subject to the law, it is not only the legislative organ's competence to posit general legal norms which is based on the constitution, but also the binding nature of these norms for those subject to the law"22.

In another passage he holds: "As it was indicated in an earlier context, the normative function of empowering someone to posit norms can be reduced to a function of commanding. (...) The higher norm empowering an individually or generally specified organ to posit lower norms can be presented as a hypothetical general norm prescribing that under the condition specified in the lower norm by the organ specified in the higher norm, the consequence specified in the lower norm posited by the organ specified in the higher norm is to occur. (...) 'Under the condition specified in the norm posited by individual $\mathrm{X}$ (or individuals $\mathrm{X}, \mathrm{Y}, \mathrm{Z} \ldots$...), the legal consequence (a coercive act) specified in the norm posited by individual $\mathrm{X}$ (or individuals $\mathrm{X}, \mathrm{Y}, \mathrm{Z} \ldots$...) is to occur'23.

In Kelsen's concept the empowering norm is "blank" in character: neither the circumstances of the actualization of an order nor its object are defined. This only happens after the performance of the establishment of the norms, the establishment being performed on the basis of the empowering norm: "The empowering norm is a blank norm. The conditioning state of affairs and the conditioned legal consequence are empty forms, that is, their content in not specified in the empowering legal norm, but they point to further specification by a legal norm to be posited by the empowered norm" 24 .

2.3 Another representative of the normative group is the Danish legal theory scholar Alf Ross. In his book "Directives and Norms" he writes: "Obligation is the fundamental directive category in which any norm may be expressed" 25 .

According to Ross the establishment of law as the source of law is associated with the competence understood as: "the legally established ability to create legal norms (or legal effects) through and in accordance with enunciations to this effect (...). The norm which establishes this ability is called a norm of competence. It states the conditions necessary for the exercise of this ability. These conditions usually fall into three groups: (1) those which prescribe what person (or persons) is qualified to perform the act which creates the norm (personal competence); (2) those which prescribe the procedure to be followed (procedural competence); and (3) conditions which prescribe the possible scope of the created norm with regard to its subject, situation, and theme (substantial competence)"26.

Most importantly for the problem under consideration, Ross asserts: "Norms of competence are logically reducible to norms of conduct in this way: norms of competence make it obligatory to act according to the norms of conduct which have been created according to the procedure laid down in them" 27.

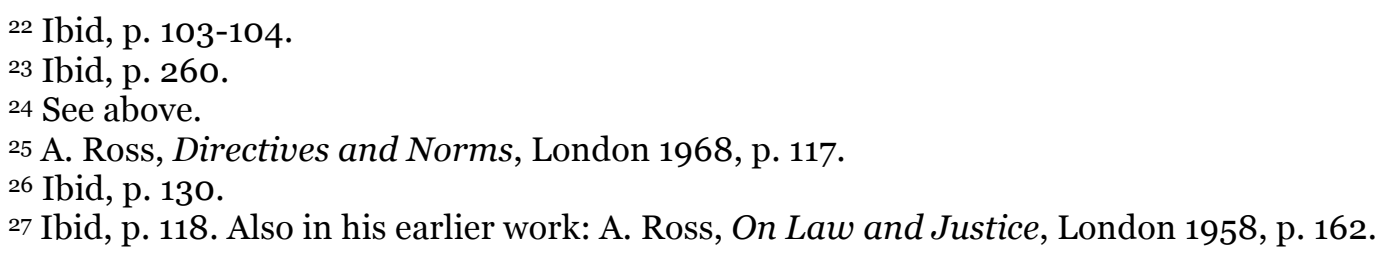


2.4 The ideas of Ross presented above have been adopted and developed by Zygmunt Ziembiński, a legal theory scholar from Poznań, who has consistently and exhaustively expounded the concept of the norm of competence ${ }^{28}$.

The assumptions made at the beginning of this paper correspond with Ziembiński's views. A norm is not the same as a provision, but the former is reconstructed from the latter. Norms are the pronouncements that order or prohibit something: there are thus no permission norms since every such instance may be reduced to the order or prohibition ${ }^{29}$. From among the various types of norm distinguished by Ziembiński, those relevant for my considerations are the socalled norms of competence, granting given individuals competences, that is the possibility of performing a conventional act which actuates or creates an obligation on an addressee of this norm ${ }^{30}$. The peculiarity of the norms of competence boils down to the fact that certain individuals decide when the obligation on other individuals is created or actuated. Therefore the norm of competence determines the legal situation of two subjects: the one who obtains the competence (the competent subject) and the one who has a duty imposed on them (the addressee of a given norm).

Following Ziembiński's view that the action of the competent subject actuates or creates the obligation on the addressee, one may divide norms of competence into two groups: those that actuate obligations and those that create obligations. And the latter - called power-conferring norms - are expressed implicitly in the provisions regulating the process of establishment of law, which is supposed to confirm the normative character of these provisions ${ }^{31}$. It is worth adding that, as Ziembiński holds, power-conferring norms are not only reconstructed from legal provisions; the so-called legal culture or legal practice also play a substantial role in the process of reconstruction of such norms $3^{2}$.

According to Ziembiński's proposal, the structure of the power-conferring norm may be as follows: "If a subject A acts in the way $\mathrm{S}$ in circumstances $\mathrm{W}$ performing $\mathrm{C}$ as a conventional act $\mathrm{Ck}$, a subject $\mathrm{B}$ should in those circumstances act in the way Cm"33.

The precision of Ziembiński's concept of the power-conferring norm as well as the grounding of the concept in a broader, coherent theoretical context worked out by him, makes deeper critical analysis, possible; although it is still possible that some weaknesses related to the concept of power-conferring norm may induce its rejection.

${ }^{28}$ As maintained in: K. Świrydowicz, Analiza logiczna pojęcia kompetencji normodawczej, Warszawa-Poznań 1981, pp. 52-53; M. Zieliński w: M. Zieliński, Dwa nurty pojmowania „kompetencji”, w: Gospodarka, Administracja, Samorząd, red. H. Olszewski, B. Popowska, Poznań 1997, s. 581; M. Matczak, Kompetencja organu administracji publicznej, Kraków 2004, p. 100.

29 See: K. Świrydowicz, S. Wronkowska, M. Zieliński, Z. Ziembiński, O nieporozumieniach dotyczacych tzw. „norm zezwalajacych”, Państwo i Prawo 1975, z. 7, pp. 57-64.

$3^{3}$ See: S. Wronkowska, Z. Ziembiński, op. cit., Poznań 1997, p. 104; Z. Ziembiński, Podstawowe..., op. cit., pp. 160-172.

${ }^{31}$ Ziemiński applies the term "power-conferring norms" also to the broader types of acts like making contracts, judgments or administrative decisions.

${ }^{22}$ See Z. Ziembiński, Problemy..., op. cit., pp. 257-260.

33 See Z. Ziembiński, Problemy..., op. cit., Warszawa 1980, p. 169. 
2.4.1 Firstly one may pose the question what exactly is the object of obligation in the case of power-conferring norms. Ziembiński's standpoint in that matter seems to be ambiguous and is interpreted variously. The norm in question is sometimes understood as a kind of meta-norm, that is the obligation to observe orders or prohibitions expressed in other norms established in accordance with this meta-norm ${ }^{34}$. Such an obligation would be without any content and in order to establish what exactly somebody is to do it would be necessary to refer to other orders or prohibitions expressed in other norms.

The object of the obligation of power-conferring norms may also be conceived as an obligation to obey the established norms which is understood as a certain mental predisposition. However, one may raise the question here whether such commands may be considered as norms of conduct, since what is required in them is a kind of mental state of affairs.

In both interpretations the content of an order expressed in a power-conferring norm is independent from an order expressed in a norm established in accordance with this norm 35 . Nevertheless, these proposals seem to be artificially constructed in order to defend the thesis that a legal norm is the only basic unit of law.

There are also interpretations that an order expressed in a power-conferring norm has a blank character and is only completed after a competent subject makes use of the competence to establish the law ${ }^{36}$. In this case the obligation would be potential initially, in the sense that "until the establishment of the general and abstract norms a subject obliged to be obedient to the competence of a norm-giver does not know what exactly is his duty. The establishment of norms actuates the duty to obey the established norms and specifies the content of the duty" 37.

However, the consequence of the above proposal is that unless the competent subject makes use of his competence, the object of obligation expressed in a power-conferring norm remains inexplicit. The conclusion which stems from that is as follows: until the competent subject makes use of his competence granted by a given power-conferring norm, we cannot consider this power-conferring norm as a norm. According to the definition of the norm of conduct as proposed at the beginning, it is "a pronouncement in accordance with the rules of the given language which is suitable to order given subjects to undertake certain conduct in a certain situation or to refrain from certain conduct in a certain situation" 38 .

To conclude, in this interpretation a power-conferring norm would be reconstructed from the two groups of provisions:

These which define who, in which procedure, and regarding what scope of things may establish the law.

34 Z. Ziembiński, M. Zieliński, Dyrektywy i sposób ich wypowiadania, Warszawa 1992, pp. 37-38. $35 \mathrm{Such}$ an idea seems to be supported by Kazimierz Swirydowicz in: K. Świrydowicz, Analiza logiczna pojęcia kompetencji normodawczej, Warszawa-Poznań 1981, pp. 54-6o.

${ }^{36}$ See S. Wronkowska, Z. Ziembiński, op. cit., pp. 35-36: „Treść nakazu zawartego w normie udzielającej kompetencji prawodawczej nie jest początkowo dokładnie określona; dopiero wówczas, kiedy podmiot, który mocą takiej normy uzyskał kompetencję prawodawczą, uczyni z tej kompetencji użytek, ustanawiając określoną normę dla podmiotów podlegających jego kompetencji prawodawczej, i ta norma znajdzie zastosowanie, adresaci normy udzielającej kompetencji prawodawczej mają zaktualizowany i dokładniej określony obowiązek postąpienia według ustanowionej dla nich w należyty sposób normy."

37 Ibid, p. 118.

${ }^{38}$ See Z. Ziembiński, Problemy..., op. cit., p. 119. 
These which define what exactly is the obligation of the given group of people (what the addressees are to do or to refrain from doing).

As is easily noticed, the second group of provisions is subsequent to the first one and is established because of that first group of provisions. However, the establishment of the second group of provisions is not performed because of any norm, since one may speak about the norm only after the competent person makes use of his competence - only then are all the elements accessible which are necessary to reconstruct the whole norm.

2.4.2 The next charge that may be raised against Ziembiński's concept of powerconferring norm is based on the observation that it is not always the case that legal norms can be reconstructed from the result of the establishment of legal provisions 39 . As has already been stated, the objects of establishment are not legal norms, but normative acts consisting of legal provisions; only from the latter can one reconstruct legal norms. The process of interpretation is not automatic (we cannot write a universal algorithm for reconstructing norms from provisions) for many reasons. It is, among other things, due to the fact that normative acts are written in natural language, blurred and ambiguous (so-called "open texture" in Hart's terminology ${ }^{40}$ ); a substantial role is also played by general clauses, as well as the ambiguity of the rules of interpretation or the rules of inference (these are the rules which prescribe how to derive norms from other norms). As the objects of establishment are normative acts, one may not exclude the situation in which it would be impossible to reconstruct the whole norm from such an established act and it would be possible to reconstruct only an element of the norm. One would have to look for the remaining elements in other normative acts, which in some cases might not yet be established.

2.4.3 The deficiency of the concept of the power-conferring norm manifests itself in the incompatibility of the textual content of this norm with the definition of the legal norm, considered as a norm of conduct. As has previously been mentioned, some interpretations of the object of obligation of the powerconferring norm lead to incompatibility with the adopted definition of the legal norm because of the impossibility of determining the object of obligation before a competent person makes use of his competence to establish provisions. This discrepancy also appears with respect to the circumstances in which a powerconferring norm is applied, as well as to the group of people to whom it is directed.

It is not always the case that the commands reconstructed from the established provisions are actuated as soon as these provisions come into force, but very frequently some other conditions set out in the established provisions must be fulfilled. Also, the range of people (addressees) identified by the established provisions may be narrower than the range identified by the powerconferring norm. Because of that, the power-conferring norm does not directly

\footnotetext{
39 Właśnie z tego punktu widzenia Wojciech Patryas szeroko przedstawia swoje krytyczne uwagi względem koncepcji normy kompetencji prawodawczej, utrzymując, iż pogląd, wedle którego stanowienie prawa jest zawsze stanowieniem całych norm prawnych, przejął Ziembiński od Kelsena. Por.: W. Patryas, Performatywy $w$ prawie, Poznań 2005, pp. 79-89.

${ }^{40}$ H. L. A. Hart, op. cit., pp. 124-136.
} 
specify its range of application, which means it does not comply with the definition of the legal norm.

3.0 Because of the weaknesses of the concept of power-conferring norm presented above, it seems to be refutable. This is also the case with the concepts of Kelsen and Ross, whose ideas were subsequently developed by Ziembiński. However, this raises the question: if not these, then what?

In order to begin the presentation of my own standpoint I have to underline two somewhat obvious features characteristic of the establishment of law. Firstly, the establishment is a kind of act of communication between individuals; secondly it is connected with the formulation of orders or prohibitions directed to some subjects - in other words, the aim of the establishment of law is to affect certain people so that they undertake behaviors they would not otherwise undertake. As has already been mentioned, however, those commands, are not formulated directly, but through the normative acts consisting of legal provisions and on the basis of the latter one reconstructs legal norms, or at least those elements of them necessary to solve a given legal problem.

The following conclusion stems from the first observation: language is the necessary instrument of the establishment of law. Indeed, legal provisions are formulated in the official language of a given state, being a variety of the ordinary language (natural language) ${ }^{41}$. What follows from this is that even in legal textbooks the first directive of interpretation is the one which formulates the presumption of ordinary language used in legal texts ${ }^{42}$. Nevertheless, the language of law (that is, the language in which legal provisions and legal norms are formulated) contains a certain number of expressions which are not used (or not commonly used) in ordinary language, or are used with a different meaning. The modification of the meanings of expressions taken from ordinary language or the introduction of new expressions is performed generally by legal definitions - that is, definitions formulated in legal text 43 .

The formulation of orders or prohibitions aimed at other people is frequently connected with using expressions containing modal operators and indicating the goal of a given declaration. Examples of such expressions include "should", "ought to", "must", "have to" 44 . However, not every provision contains such modal expressions, as one may observe: more often the provisions have a descriptive form ${ }^{45}$. This leads to the conclusion that the normative character of legal

\footnotetext{
${ }^{41}$ Maciej Zieliński utrzymuje, że na gruncie języka polskiego poprawniejsze byłoby użycie wyrażenia „język ogólny”. Por.: M. Zieliński, op. cit., s. 132-139.

42 Jak wyżej, s. 132-133.

43 Więcej na temat definicji legalnych: M. Zieliński, op. cit., s. 188-205. W kwestii języka prawnego:

Z. Ziembiński, Problemy..., op. cit., s. 81-93.

44 Oczywiście należy zdać sobie sprawę z wieloznaczności takich wyrażeń jak „musi” czy „powinien”. Por.: Z. Ziembiński, Logika praktyczna, Poznań 1996, s. 121-128; M. Zieliński, op. cit., s. 154-158. Trzeba mieć także na uwadze, że wyrażenia typu „ma obowiązek” są traktowane jako wyrażenia deontyczne - wyrażenia nie tyle służące do wyznaczenia komuś nakazów ile raczej służące do stwierdzenia obowiązywania owych nakazów.

45 Por. Z. Ziembiński, M. Zieliński, Dyrektywy..., op. cit., s. 106.
} 


\section{Investigationes Linguisticae, vol. XVII}

provisions is determined not by the vocabulary used in a given act, but by the context of its creation.

Taking into account the above remarks, it is possible to formulate a proposal regarding the function of the provisions regulating the process of the establishment of law. These provisions seem to serve to determine whether a specific instance was a case of formulating the normative announcement - the instance of the establishment of law. In other words, the provisions in question express definitions regulating what is to be understood as the establishment of law by assigning to the given acts the meaning (the notion) of the establishment of law.

Similarly to legal norms expressed indirectly in provisions, definitions of the establishment of law are generally not expressed directly, but are reconstructed from legal provisions. Such a reconstruction requires taking into account many provisions as well as opinions of doctrine or even the broader legacy of legal culture, which is found in the writings of some legal scholars as common practice in the process of reconstructing legal definitions ${ }^{46}$.

As a result of the operation of interpretation one may obtain a definition containing the structure: "For every $\mathrm{x}(\mathrm{P}(\mathrm{x}) \equiv \mathrm{S}(\mathrm{x}))$ ", where " $\mathrm{P}$ " would be a predicate denoting a situation regulated by legal provisions by characterizing the subjects, circumstances and behaviors. The defining expression would be a predicate " $\mathrm{S}$ " understood as " $\mathrm{x}$ is the establishment of law". The performance of the defined acts by the defined subjects in the defined circumstances qualifies these acts as the situation denoted by the predicate "S".

It must be stressed here that in the above proposed definition the expression "the establishment of law" refers to the set of human acts realized in the circumstances indicated. Therefore it is different from the usual act of defining understood as the replacement of one expression by another. However, the indication of these acts is not performed directly, but through the expressions describing them.

The question which may arise here is related to the normative character of the provisions under analysis, understood as expressing definition. The answer may be put in a broader context depending on the attitude towards the normative character of legal definitions in general. It is possible to distinguish two sorts of standpoints regarding this problem: normative and non-normative ones. Maciej Zieliński, who is considered to be a member of the first group, holds that legal definitions are provisions from which one reconstructs legal norms of a special kind, that is directives of interpretation which order one to substitute one expression for another, which is connected with the order of combining the meaning of the defining expression with the expression defined (definiendum) ${ }^{47}$.

3.1 With reference to the question about the normative character of the provisions regulating the process of establishment of law it is possible to formulate at least one more answer, based on an obvious point, even for somebody who is not a lawyer. Clearly the establishment of law is not a single act of a single person. On the contrary, it is a very complicated process of many acts undertaken by various

46 Por. W. Patryas, Rozważania o normach prawnych, Poznań 2001, s. 118-129.

47 Por. M. Zieliński, op. cit., s. 203-205; Z. Ziembiński, M. Zieliński, op. cit., s. 99; L. Nowak, Spór o definicje legalne a sposób pojmowania „prawodawcy”, Państwo i Prawo 1969, z. 3, s. 510-515. 
individuals organized in various groups connected with each other by many relations: what is more, it is a process extended in time.

This point is usually omitted in considerations dealing with the problem of the normative character of provisions regulating the process of establishment of law. However, this apparently trivial observation allows us to draw some far-going conclusions. Because of the fact that in the establishment of law there are so many different acts undertaken by various individuals, acts which moreover are extended in time, one may hold that such a process is not regulated by one norm or rule (in the case of the non normative group) but we have in fact a number of norms inter-related with one another, among other things in the specific sense that all of them refer to the process of establishment of law.

If we consider the establishment of law performed by the Polish Parliament, the first act in that process would be its initiation performed as a legislative initiative carried out by competent subjects (for instance: the Cabinet, President, 46 members of the Sejm, the group of 100,000 citizens). The act of legislative initiative, which is the act performed in accordance with the appropriate norm of competence, actuates the duty to consider the proposal in the way regulated by subsequent norms that are found in the relevant legal provisions; in other words, it starts the whole process of establishment.

Subsequently the proposal is discussed in the Sejm in three readings (which may be performed in the presence of all members of Parliament or in the appropriate commissions). If the Sejm passes the proposal it actuates the duty of the examination of the bill by the Senat. Depending on the Senat's decision (which may in a particular case make no decision, which is found to be approbation of the project proposed by the Sejm), it actuates certain obligations or competences of the Sejm or President. In special circumstances the latter has a competence to sign a bill, put a veto on it or move it to the Constitutional Court to check the conformity of the bill with the Constitution or other acts of a higher order. The very last duty in the process of the establishment of law (provided that the process is successful) actuated by the signature of the President on a bill is the duty of promulgation of a given bill in the Journal of Laws.

From the above very brief sketch of the process of the establishment of law in accordance with the Polish legal system one may draw the conclusion that the legislative procedure is not to be bound with one norm but is a kind of a chain of norms: moreover, a chain which splits depending on the number of possible acts that are at the disposal of the individuals at a given stage of this process (for instance, as stated above, the President on receiving a bill from the Sejm may sign it, veto it or ask the Constitutional Court to check its constitutionality. There are thus in that case three norms of competence and additionally one norm ordering to perform one of these acts). To summarize, the norm of competence granting the competence to initiate the process of the establishment of law is the first link of such a chain. The last one is the norm which orders promulgation of the bill.

Unfortunately, the limited scope of this paper does not permit more precise analysis of the particular links in the chain regulating the process of the establishment of bills in the Polish legal system. However, it is worth mentioning that the actualization of the duties included in some particular norm depends on the fulfilment of duties expressed in some former norm (for example, the execution of a norm requiring the President to sign a bill or to veto it or to ask the 
Constitutional Court to check its conformity with the Constitution, actuates, in accordance with the undertaken act, a duty to promulgate a bill or a duty of the Sejm to vote on the President's veto or a duty of the Constitutional Court to consider charges against the bill).

4.0 The proposals presented in this paper are merely a sketch of two concepts which attempt to answer the question about the normative character of provisions regulating the process of the establishment of law. In both cases the normative character of the provisions in question is confirmed while the concept of a powerconferring norm is rejected as erroneous and useless. The two proposals are not mutually exclusive: that is, the provisions regulating the process of establishment of law may be conceived as expressing indirectly a legal definition of the establishment of law as well as expressing indirectly the chain of norms involved in the establishment of law.

\section{Bibliografia}

Bravo, J. 1997. Alternative phonetics: no phonemes, no phones. Phon Phen: Phony Publishing House.

Kowalsky, J., Novak, P. 1998. About new tendencies in informal linguistics. w: 1st Workshop on Crazy Grammars. New York. pp. 200-203.

Jackowski, B. 2006. Wstęp. w: Tomaszewski, A. Zapiski książkoroba. Warszawa: Wydawnictwo Do.

Yadvaniji, A. 1969. Yoga for phoneticians. Delhi: National Publishing House. 